\title{
The impact of the condensation process on the degree of cleaning of flue gases from acidic compounds
}

\author{
Piotr Szulc ${ }^{1, *}$, Tomasz Tietze ${ }^{1}$, and Daniel Smykowski ${ }^{1}$ \\ ${ }^{1}$ Wroclaw University of Science and Technology, Wybrzeże Wyspiańskiego 27, 50-370 Wroclaw, \\ Poland
}

\begin{abstract}
The paper presents studies on the impact of the process of condensation of water vapour on the process of cleaning of flue gases from acidic compounds. The measurements were carried out on a pilot-scale plant for waste heat recovery from flue gases, taking into account the process of condensation of the water vapour contained in them. The plant was connected to a lignite-fired power unit with a capacity of $360 \mathrm{MW}$ located at PGE GiEK S.A., Bełchatów Power Plant Branch. The impact of the condensation of water vapour on the reduction of sulphur, chlorine and fluorine forming acidic compounds was examined. The studies show that the condensation process is conducive to removal of acidic compounds from flue gases.
\end{abstract}

\section{Introduction}

In the majority of coal-fired power plants, flue gases, after cleaning in a desulphurization plant, are directed to a chimney. The temperature of flue gases is higher than the temperature of condensation of water vapour, because the condensing water in combination with sulphur compounds causes, inter alia, the corrosion of the flue gas duct walls. However, there are plants, in which flue gases are cooled below the temperature of condensation of water vapour. Such solutions enable the recovery of waste heat from flue gases and a reduction in pollution emissions. The most interesting plants are those used in Scandinavia, in which waste heat recovery systems are integrated with flue gas desulphurization systems [5,6,7]. In 1998, a flue gas cleaning system with condensation of the water vapour contained in flue gases was launched in Gothenburg [5]. In this system, the temperature of flue gases is gradually reduced from $220^{\circ} \mathrm{C}$ to $140^{\circ} \mathrm{C}$ upstream of the flue gas cleaning reactor. In the reactor, flue gases are subjected to preliminary cleaning and in addition they cooled down to the temperature of $60^{\circ} \mathrm{C}$ and then directed to the condensing part, where their temperature is reduced to $40^{\circ} \mathrm{C}$. The process of condensation increases the reduction in the emission of pollutants. After cleaning, the flue gases are heated to the temperature of $150^{\circ} \mathrm{C}$ in order to avoid the corrosive action on the duct and chimney walls. A similar solution was implemented in the Holstebro power plant [7]. In this case the flux of heat recovered from flue gases is approximately

* Corresponding author: piotr.szulc@pwr.edu.pl 
14 MW. This is not a large value, as the main objective of the system is to reduce the emission of pollutants. Like in the power plant in Gothenburg, flue gases must be heated upstream of the chimney duct. In the largest power plant in Denmark in Copenhagen, the maximum flux of the recovered heat, which is used for district heating purposes, is $17 \mathrm{MW}$. Another interesting solution is the heat and water recovery system with flue gas condensation implemented in the power plant in Sønderborg in 2007 [6]. The condensate formed as a result of condensation of water vapour is returned to the flue gas cleaning process and thereby no fresh water is used during normal operation. The recovered waste heat with the flux of $6 \mathrm{MW}$ is directed to a district heating network. However, in all these cases the flux of the recovered heat is low, while the primary purpose of these plants is to clean flue gases.

Large streams of water are used for the needs of cleaning of flue gases and process gases. In order to limit the consumption of fresh water, it is advantageous to use condensation systems for cooling down the flue gases coming from the combustion of lignite due to high moisture content. As shown in $[1,2,3,4]$, the use of condensing heat exchangers enables recovery of a large flux of waste heat and reduces the emission of the pollutants. In Poland, the first condensing heat exchanger for recovery of waste heat from flue gases was built in the Białystok S.A. combined heat and power plant in 2015. The flue gases coming from a biomass-fired boiler are subjected to the processes of cooling and cleaning by sprinkling them with the condensate. As a result of this process, significant amounts of chlorides, heavy metals and dust are removed from flue gases. Then, the flue gases get to the condenser, in which water vapour is condensed. The recovered heat of condensation is directed to a municipal district heating network. Contaminated condensate coming from flue gases is subjected to the process of cleaning through microfiltration, ultrafiltration and reverse osmosis filter. The condensate obtained in this way is reused for industrial processes in the combined heat and power plant. The use of the heat recovery system significantly reduces the emission of pollutants into the atmosphere, as well as increases the efficiency of the combined heat and power plant through recovery of heat and water from flue gases. The paper presents the results of studies on the impact of condensation of water vapour from flue gases coming from the combustion of lignite on the reduction of emissions of pollutants, i.e. acidic compounds.

\section{Test rig}

The tests have been carried out in a pilot-scale plant for recovery of waste heat from flue gases, which was built at PGE Górnictwo i Energetyka Konwencjonalna S.A., Bełchatów Power Plant Branch. The pilot-scale plant was supplied with flue gases from the combustion of lignite in a power unit with a capacity of $360 \mathrm{MW}$ [2]. Diagram of the plant is shown in Fig. 1, while its view is presented in Fig. 2. The main element of the pilot-scale plant for waste heat recovery was a shell and tube condensing heat exchanger with a capacity of $312 \mathrm{~kW}$. The heat exchanger was installed in the flue gas duct downstream of the main induced draft fan and upstream of the flue gas desulphurization system. In order to adjust the mass flow rate of flue gases passing through the condensing heat exchanger, a supporting fan was installed upstream of the heat exchanger. Flue gases flowing through the condensing heat exchanger were cooled with water using a system of PTFE pipes. As a result of cooling down the flue gases to a temperature below the dew point, condensation of the water vapour contained in the flue gases and liquefaction of the condensate took place. The condensate collected by the tray was directed to the sewage system. The pilot-scale plant was equipped with a measurement recording system as well as systems for controlling the main thermal and flow parameters. In order to determine the composition of the flue gases, there were made holes, through which samples were collected at the inlet and at the outlet of the condensing heat exchanger. The measurements were carried out continuously for 220 minutes. 


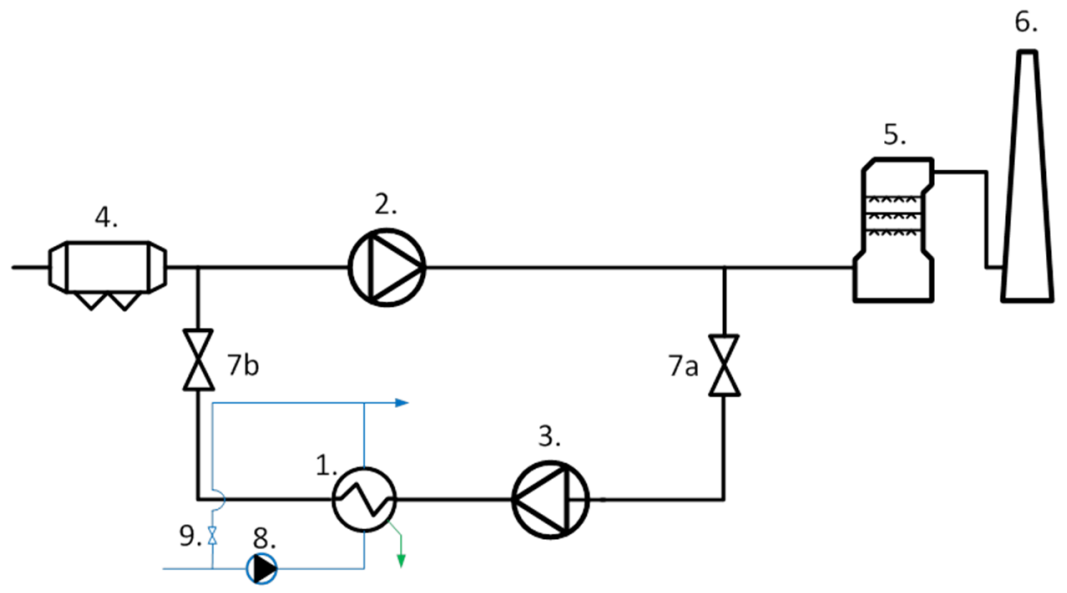

Fig. 1. Diagram of the pilot-scale plant for investigating waste heat recovery from flue gas. 1-condensing heat exchanger, 2 - main induced draft fan in the flue gas duct, 3 - supporting fan, 4 - system for removal of ash from flue gas, 5 - flue gas desulphurization system, 6 - chimney, 7 - shut-off gate valve, 8 - cooling water pump, 9 - control solenoid valve

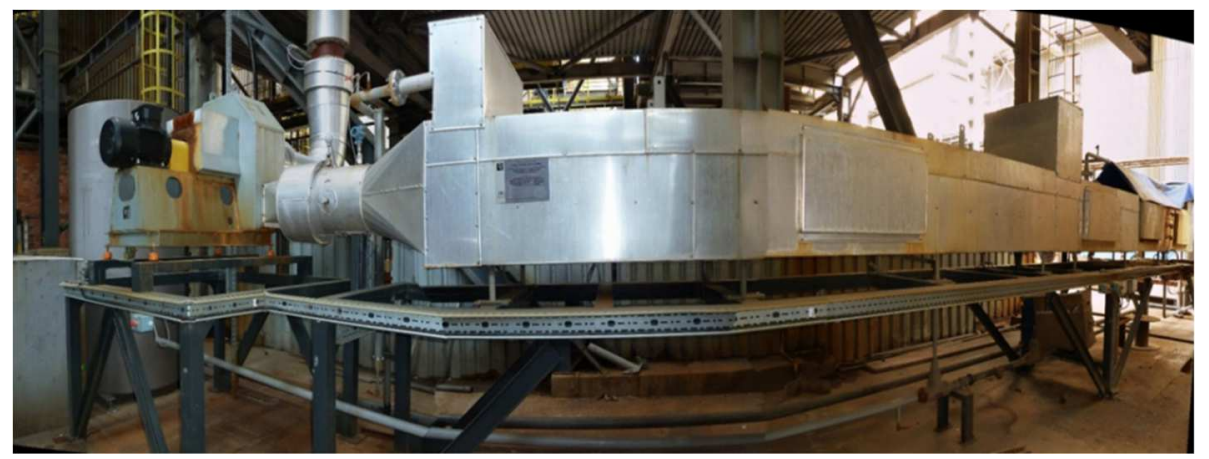

Fig. 2. View of the test rig

\section{Research methodology}

The measurements of the composition of flue gases were carried out on a continuous basis. Their aim was to determine the degree of reduction in content of pollutants present in flue gases as a result of the condensation of water vapour. The scope of the studies presented in the paper covered measurements of concentrations of $\mathrm{NOx}, \mathrm{SO}_{2}, \mathrm{HCl}$, and $\mathrm{HF}$, as well as measurements of the volumetric flow rate of flue gases. Sampling of the values took place at a frequency of $1 \mathrm{~Hz}$ and the recorded values were averaged every 60 seconds. The values averaged over the period of 600 seconds were taken for the analysis. In order to draw in a sample of flue gases, a heated probe, heated hoses and a particulate filter were used. Dustfree flue gases were transported through heated hoses to a diaphragm pump with a heated head. A part of the flue gas stream was directed to a two stage cooler that removed the water vapour contained in the flue gases, while dry and clean gas was directed to the analyser. The main measurements of the concentration of gas components in the flue gases were performed in the analyser. The uncertainty of the determination of the content and concentration was as follows: volumetric flow - approx. 3.3\%, particulate matter content - approx. 5.7\%, sulphur dioxide content - approx. $2.0 \%$, nitrogen oxides content - approx. $7.0 \%$, carbon monoxide 
content - approx. $3.0 \%$, hydrogen chloride content - approx. 4.0\%, hydrogen fluoride content - approx. $12 \%$, moisture content - approx. $7 \%$, oxygen content - approx. $2 \%$.

\section{Analysis of the chemical composition of flue gases}

In the condensing heat exchanger, to which the flue gases containing water-soluble and/or water-reactive compounds are supplied, there occur both physical and chemical processes. Water in the liquid phase, which occurs as a result of condensation, absorbs a certain part of these compounds, while some of them not only dissolve in water, but also react with it, which leads to the formation of aggressive compounds. Acidic compounds and those reacting with water to form acids are of particular importance in this case. This group includes, inter alia, nitrogen and sulphur oxides, as well as hydrogen chloride and hydrogen fluoride. These gases form acids as a result of the reaction with water. In the case of nitrogen oxides $\left(\mathrm{NO}_{\mathrm{x}}\right)$, the following reactions are of greatest importance:

$$
\begin{gathered}
2 \mathrm{NO}+\mathrm{O}_{2} \leftrightarrow 2 \mathrm{NO}_{2} \\
2 \mathrm{NO}_{2} \leftrightarrow \mathrm{N}_{2} \mathrm{O}_{4} \\
2 \mathrm{NO}_{2}+\mathrm{H}_{2} \mathrm{O} \rightarrow \mathrm{HNO}_{2}+\mathrm{HNO}_{3} \\
3 \mathrm{NO}_{2}+\mathrm{H}_{2} \mathrm{O} \leftrightarrow 2 \mathrm{HNO}_{3}+\mathrm{NO} \\
\mathrm{N}_{2} \mathrm{O}_{4}+\mathrm{H}_{2} \mathrm{O} \leftrightarrow \mathrm{HNO}_{3}+\mathrm{HNO}_{2} \\
2 \mathrm{HNO}_{2} \leftrightarrow \mathrm{NO}+1 / 2 \mathrm{~N}_{2} \mathrm{O}_{4}+\mathrm{H}_{2} \mathrm{O} \\
3 \mathrm{HNO}_{2} \leftrightarrow 2 \mathrm{NO}+\mathrm{HNO}_{3}+\mathrm{H}_{2} \mathrm{O} \\
\mathrm{NO}+3 / 4 \mathrm{O}_{2}+1 / 2 \mathrm{H}_{2} \mathrm{O} \leftrightarrow \mathrm{HNO} 3
\end{gathered}
$$

which result in formation of nitric acid $(\mathrm{V})-\mathrm{HNO}_{3}$. Sulphur oxides $\left(\mathrm{SO}_{\mathrm{x}}\right)$ also react with water to form an acid, in particular $\mathrm{SO}_{2}$, which usually is the main sulphur compound contained in flue gases. Depending on the conditions, e.g. presence of water and oxygen, sulphur dioxide may oxidise to sulphur trioxide

$$
\mathrm{SO}_{2}+1 / 2 \mathrm{O}_{2} \leftrightarrow \mathrm{SO}_{3},
$$

which in turn reacts with water, which results in formation of sulphuric acid (VI)

$$
\mathrm{SO}_{3}+\mathrm{H}_{2} \mathrm{O} \leftrightarrow \mathrm{H}_{2} \mathrm{SO}_{4} \text {. }
$$

Two other gases present in the composition of the flue gases: $\mathrm{HCl}$ and $\mathrm{HF}$, after the dissolution in water, form hydrochloric and hydrofluoric acid, respectively. As a result, the condensate discharged from the heat exchanger is a mixture of four strong acids (this is confirmed by measurements of $\mathrm{pH}$ of the condensate), which shows an aggressive action in relation to the materials (mainly metals), of which the plant is built. This is proved by advanced corrosion processes leading to the destruction of the elements that are in direct contact with the condensate.

The analysis of the content of individual components of flue gases identified at the inlet and at the outlet of the heat exchanger in combination with the analysis of the composition of the condensate allows determining the predominant chemical processes accompanying the phenomenon of condensation.

The content of the flue gas components analysed at the inlet and at outlet of the condensing heat exchanger is shown in Figs. 3-6, while their reduction - in Fig. 7. 


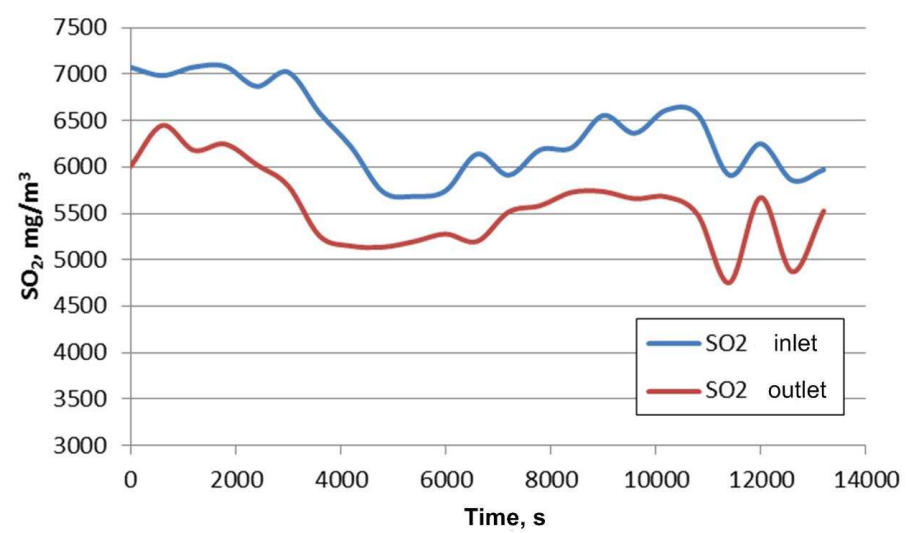

Fig. 3. Content of $\mathrm{SO}_{2}$ in flue gases at the inlet and at the outlet as a function of time

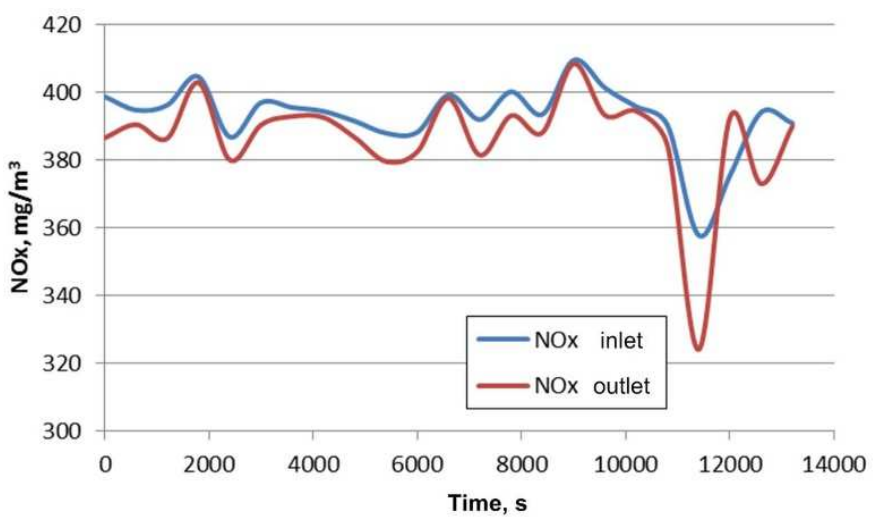

Fig. 4. Concentration of $N O_{x}$ at the inlet and at outlet of the condensing heat exchanger as a function of time

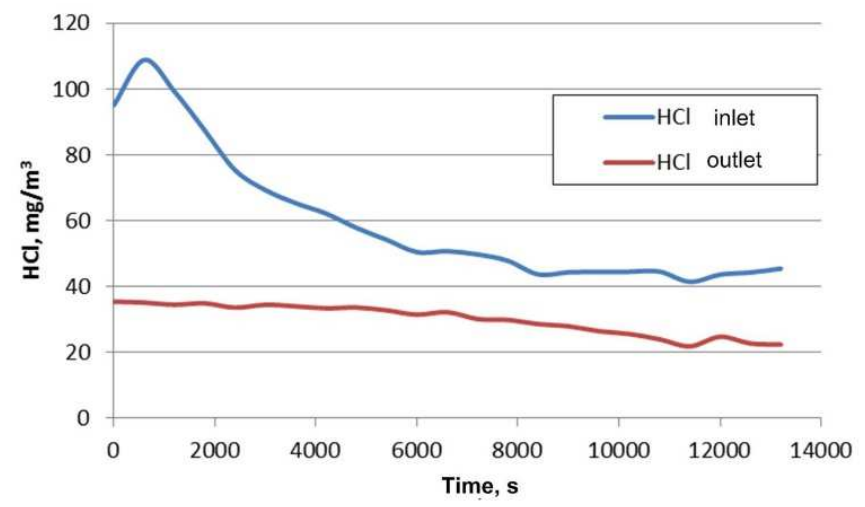

Fig. 5. Content of $\mathrm{HCl}$ in the flue gases upstream and downstream of the condensing heat exchanger as a function of time

Among the acidic compounds analysed, sulphur dioxide has the largest share in the flue gases - both at the inlet and at the outlet (Fig. 3). The components with the second largest content are nitrogen oxides (Fig. 4), while other components occur in much smaller amounts. A comparison of the content of individual gases in the flue gases allows determining which 
of them are absorbed to the highest degree by the condensate formed in the heat exchanger. The largest difference in the concentration between the inlet and outlet can be noticed for hydrogen fluoride $(\mathrm{HF})$ and for hydrogen chloride $(\mathrm{HCl})$. In turn, the concentration of nitrogen oxides (NOx) changes only slightly. A significant difference also occurs in the case of sulphur dioxide $\left(\mathrm{SO}_{2}\right)$, which is shown in Fig. 3.

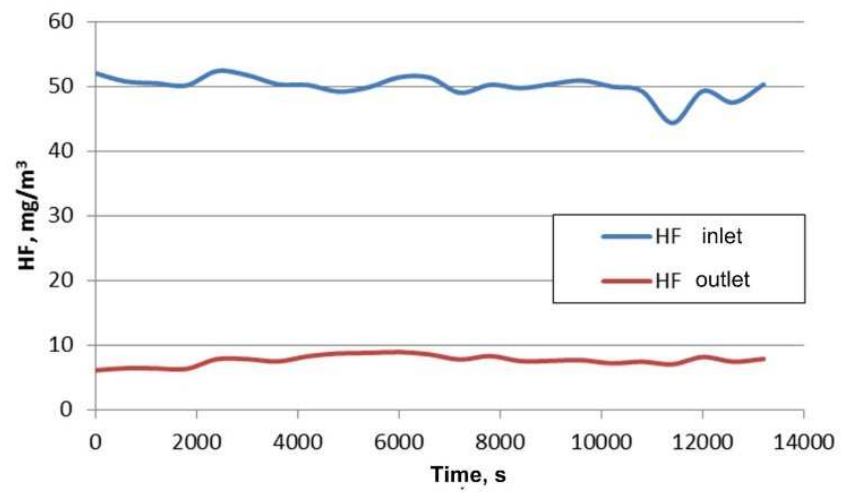

Fig. 6. Content of HF in the flue gases upstream and downstream of the condensing heat exchanger as a function of time

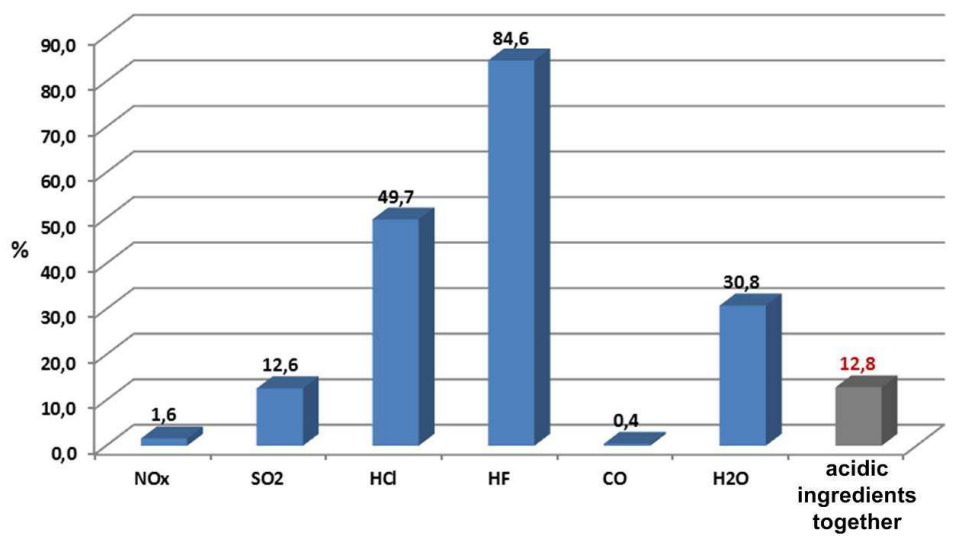

Fig. 7. Reduction in the content of $\mathrm{NOx}, \mathrm{SO}_{2}, \mathrm{HCl}, \mathrm{HF}, \mathrm{CO}, \mathrm{H}_{2} \mathrm{O}$ and the total reduction of acidic components in the condensing heat exchanger, \%

The difference in the concentration of individual components in the inlet and outlet flow of flue gases was characterized by the reduction, \% (Fig. 7), defined as:

$$
R=\frac{\left(c_{1}-c_{0}\right)}{c_{1}} \cdot 100 \%
$$

where :

$R \quad-\quad$ reduction, $\%$,

$c_{1} \quad-\quad$ content (concentration) of the component at the inlet of the heat exchanger, $\mathrm{mg} / \mathrm{m}^{3}$,

$c_{0} \quad-\quad$ content (concentration) of the component at the outlet of the heat exchanger, $\mathrm{mg} / \mathrm{m}^{3}$. 
Fig. 7 shows that the content of hydrogen fluoride changes to the highest degree as a result of using a condensing heat exchanger. The flue gases leaving the heat exchanger contain less than $20 \%$ of the HF contained in the flue gases entering the heat exchanger, while in the case of $\mathrm{HCl}-$ it is approximately half. After passing the flue gases through the heat exchanger, the content of $\mathrm{SO}_{2}$ drops by only $12.6 \%$, however it should be emphasized that there is much more sulphur dioxide in the flue gases than other components. As a result, this allows reducing the emission of sulphur dioxide to a significant degree. The total percentage of the reduction in the content of acidic components, i.e. $\mathrm{HF}, \mathrm{HCl}, \mathrm{NOx}$ and $\mathrm{SO}_{2}$ is $12.8 \%$, which is almost the same as in the case of the reduction in the content of $\mathrm{SO}_{2}$. This is due to the fact that sulphur dioxide has a predominant share in the flue gases among these compounds.

When comparing the level of reduction in the content of individual components in the flue gases, it can be observed that it shows a certain correlation to the solubility of these components in water. It happens like that because the time of contact between the flue gases and the condensate is the same for each component.

\section{Analysis of the chemical composition of the condensate}

Fig. 8 shows the content of the selected ions in the condensate. As expected, sulphate ions (VI) have the largest share in the condensate. They are formed as a result of the reaction of sulphur dioxide with water. Although only slightly more than $12 \%$ of $\mathrm{SO}_{2}$ is absorbed in the condensate (assuming that the entire loss of the component in the flue gases gets to the condensate), a large amount of this gas in the flue gases causes that ions of $\mathrm{SO}_{4}{ }^{2-}$ are a predominant component of the condensate. Among the ions that are acid radicals, the fluoride ion is in the second place in terms of the content in the condensate and is followed by the chloride ion. This means that the presence of three acids (sulphuric (VI), hydrofluoric and hydrochloric) is responsible for the aggressive properties of the condensate. The presence of acids in the condensate is confirmed by its $\mathrm{pH}$ value of 2.6.

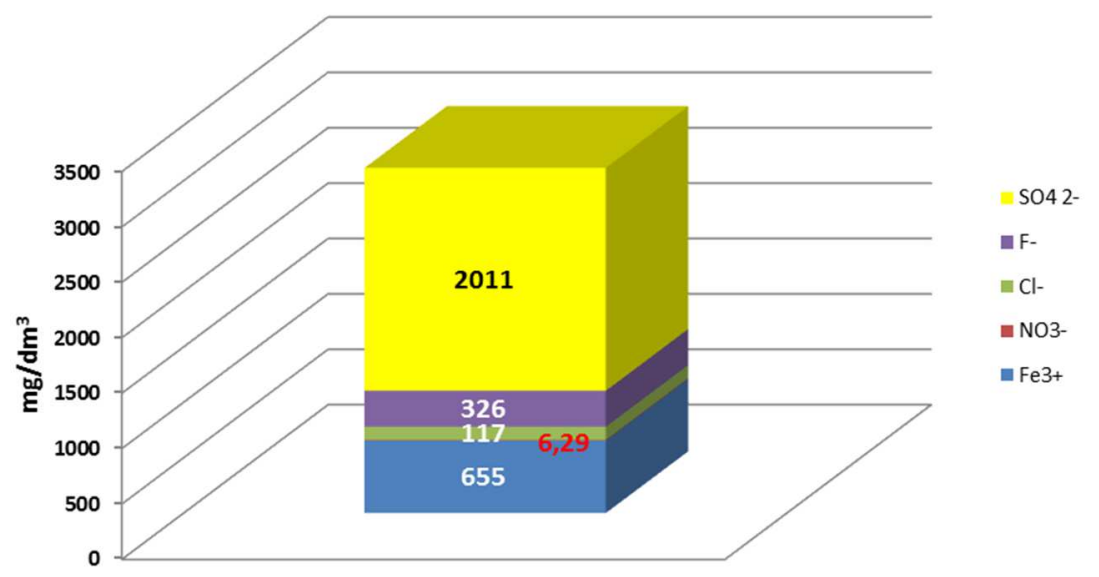

Fig. 8. Content of $\mathrm{SO}_{4}{ }^{2-}, \mathrm{F}, \mathrm{Cl}, \mathrm{NO}_{3}{ }^{-}, \mathrm{Fe}^{3+}$ in the condensate, $\mathrm{mg} / \mathrm{dm}^{3}$

It is noteworthy that the condensate contains a significant amount of iron - its content in the condensate is the largest among all metal ions. This is most likely caused by the corrosive processes consisting in an aggressive action of acidic condensate on steel, from which the plant is built. 


\section{Conclusion}

The paper presents studies on the impact of the process of condensation of water vapour on the process of cleaning of flue gases from acidic compounds, such as sulphur, nitrogen, chlorine and fluorine compounds. The measurements were carried out on a pilot-scale plant for waste heat recovery from flue gases, taking into account the process of condensation of the water vapour contained in them. The plant was connected to a lignite-fired power unit with a capacity of $360 \mathrm{MW}$ located at PGE GiEK S.A., Bełchatów Power Plant Branch. The studies were carried out by measuring the content of acidic compounds upstream and downstream of the heat exchanger. The content of these compounds in the condensate was also examined. Based on the research results presented, it can be concluded that the condensation of water vapour from flue gases has a decisive impact on the composition of flue gases downstream of the heat exchanger. The concentration of hydrogen fluoride is reduced to the highest degree - on average by $85 \%$, while hydrogen chloride is reduced by $47 \%$ and sulphur dioxide by $12.5 \%$. The concentration of nitrogen oxides is reduced only to a small extent - by $1.6 \%$. From the analyses of the condensate it appears that $\mathrm{SO}_{4}{ }^{2-}$ ions constitute a predominant component of the condensate. Among the ions that are acid radicals, the fluoride ion is in the second place in terms of the content in the condensate and is followed by the chloride ion. The conclusion is that the condensation process is conducive to removal of acidic compounds from flue gases.

\section{References}

1. Szulc P., Tietze T., Wójs K. Numerical analysis of a waste heat recovery process with account of condensation of steam from flue gases, Archives of Civil and Mechanical Engineering. 15, 4,:pp 1017-1023, (2015)

2. Wójs K., Szulc P., Tietze T. Odzysk niskotemperaturowego ciepła odpadowego ze spalin wylotowych, scientific editor: Wójs K., Warszawa, Polish Scientific Publishers PWN,pp:1-111, (2015)

3. Szulc P., Tietze T., Wójs K. Wpływ strumienia objętości spalin na strumień niskotemperaturowego ciepła odpadowego odzyskanego w kondensacyjnym wymienniku ciepta. Analiza systemów energetycznych: collective work, edited by Bohdan Węglowski, Piotr Duda. Kraków: Publishing House of the Cracow University of Technology, pp. 317-330 (in Polish), (2013)

4. Mikielewicz D., Wajs J., Ziółkowski P., Mikielewicz J., Utilisation of waste heat from the power plant by use of the ORC aided with bleed steam and extra source of heat, Energy, 97, pp. 11-19, (2016)

5. Condensing flue gas cleaning system with electric power and heat production at the waste incineration heating plant in Gothenburg, Götaverken Miljö AB, www.gmab.se.

6. Extended energy recovery using flue gas condensation with condensate treatment, Götaverken Miljö AB. www.gmab.se.

7. Multi-functional wet ADIOX® scrubbers with integrated energy recovery, Götaverken Miljö AB. www.gmab.se. 